\title{
Reoxidation of Bioreduced Uranium Under Reducing Conditions
}

Jiamin Wan ${ }^{1 *}$, Tetsu K. Tokunaga ${ }^{1}$, Joern Larsen ${ }^{1}$, Zuoping Zheng ${ }^{1}$, Eoin Brodie ${ }^{2}$, Zheming Wang ${ }^{3}$, Don Herman ${ }^{2}$, Terry C. Hazen ${ }^{1}$, Mary K. Firestone ${ }^{2}$, \& Stephen R. Sutton $^{4}$

${ }^{1}$ Lawrence Berkeley National Laboratory, Berkeley, California 94720, USA

${ }^{2}$ University of California, Berkeley, California 94720, USA

${ }^{3}$ Pacific Northwest National Laboratory, Richland, WA 99352, USA

${ }^{4}$ University of Chicago, Chicago, Illinois 60637, USA

Uranium mining and processing for nuclear weapons and fuel have left thousands of sites with toxic levels of this actinide in soil and ground water ${ }^{1}$. An emerging strategy for remediating such environments involves using organic carbon to promote microbially-mediated reduction and precipitation of insoluble U(IV) minerals ${ }^{2-4}$. Although previous $U$ bioreduction studies have shown promising results, they were of short duration (up to a few months). Our longer-term (20 months) laboratory study using historically contaminated sediment has alarmingly shown that microbial reduction of $U$ was transient even under reducing (methanogenic) conditions. Uranium was reductively immobilized during the first 100 days, but later (150 to 600 days) reoxidized and mobilized, although a microbial community capable of reducing $U(V I)$ remained through the end of the experiment. The formation of $\mathrm{Ca}_{2} \mathrm{UO}_{2}\left(\mathrm{CO}_{3}\right)_{3}$ complexes $^{5}$ (caused by the elevated carbonate concentration from microbial respiration and presence of calcium) drove the $\mathrm{U}(\mathrm{IV}) / \mathrm{U}(\mathrm{VI})$ reduction potential to much more reducing conditions. Fe(III) and Mn(IV) were found to be likely terminal electron acceptors (TEAs) for U reoxidation. Thus, $U$ remediation by organic carbon based reductive precipitation is not sustainable in calcareous, neutral to alkaline soils and ground waters 
The mobility of uranium depends strongly on its oxidation state, with U(IV) species being much less soluble than U(VI) species under most environmental conditions $^{6}$. Based on findings that a number of Fe- and S-reducing bacteria also reduce $\mathrm{U}(\mathrm{VI})$, enzymatically as well as indirectly ${ }^{7-10}$, a strategy under development for remediating U-contaminated soil and groundwater is based on promoting reductive precipitation of low solubility U(IV) minerals. Emerging techniques rely on injecting organic carbon (OC) into contaminated sediments in order to stimulate direct or indirect microbial U(VI) reduction to U(IV) solids ${ }^{2-4}$. However, accounts of OC-stimulated bacterial $U$ reduction have only reported results for short times after conversion of $\mathrm{U}(\mathrm{VI})$ to $\mathrm{U}(\mathrm{IV})$. Although dissolved oxygen, nitrate and denitrification products have been shown to oxidize $\mathrm{U}^{11-13}$, such results are expected from inspection of the redox ladder. When unperturbed by influxes of highly oxidizing TEAs, U(IV) is commonly assumed to be stable in reducing sediments. This study examines the stability of bioreduced U under such conditions.

The experiment was conducted on soils heavily contaminated from past $U$ waste disposal ( $\mathrm{U}$ concentration of $206 \mathrm{mg} \mathrm{kg}^{-1}$ ), obtained from Oak Ridge National Laboratory $^{14}$ (Tennessee, USA). The soils were packed into columns (200 mm length, $32 \mathrm{~mm}$ ID), and permeated with $10.7 \mathrm{mM}$ Na-lactate solution (32 mM OC, $\mathrm{pH}$ 7.2) to stimulate $\mathrm{U}$ bioreduction by the native microbial community. The solution was supplied at a pore fluid velocity of $20 \mathrm{~mm} \mathrm{~d}^{-1}$ for 215 days, and thereafter decreased to $10 \mathrm{~mm} \mathrm{~d}^{-1}$. Concentrations of U, OC, inorganic carbon (IC), methane, carbon dioxide, iron, manganese, calcium, and $\mathrm{pH}$ were determined in effluents. Redox potentials were measured within columns with Pt electrodes, and also calculated based on ratios of methane and $\mathrm{CO}_{2}$ concentrations. Oxidation states of $\mathrm{U}$ within the soil were measured within columns (days 117 and 356) by synchrotron micro-X-ray absorption near edge structure ( $\mu$-XANES) spectroscopy ${ }^{15}$. In order to determine the aqueous uranyl species within column effluents, fluorescence spectroscopic and lifetime measurements were 
conducted $^{5,16}$. Bacterial community dynamics during U-reduction and reoxidation processes were monitored by using both terminal restriction fragment length polymorphism (TRFLP) and high density oligonucleotide array ${ }^{17}$ analyses.

The measured steady-state $\mathrm{pH}, \mathrm{CO}_{2}$ partial pressure $\left(\mathrm{PCO}_{2}\right)$, pe, and carbon concentrations are shown in Table 1. By day 120, most of the input lactate ( $>95 \%)$ was being consumed, with $\mathrm{CH}_{4}, \mathrm{HCO}_{3}{ }^{-}$, and $\mathrm{CO}_{2}$ being the dominant products, (accounting for $75 \%$ of the influent C). Data from Pt electrodes indicate that microbial respiration drove redox potentials down to reducing conditions, with an average Eh of $-200 \mathrm{mV}$ (pe $=-3.4$ ) by day 100 when U(VI) bioreduction was complete. Calculations based on measured elevated $\mathrm{PCO}_{2}$ and $\mathrm{PCH}_{4}$ yielded even lower $\mathrm{pe}=-4.2$.

Table 1. Measured steady-state solution chemistry

\begin{tabular}{|l|c|c|c|}
\hline & & Influent & Effluent \\
\hline $\mathbf{p H}$ & & 7.2 & $7.4 \pm 0.14^{\mathrm{a}}$ \\
\hline $\mathbf{p e}$ & & $>0$ & $-3.4 \pm 1.0^{\mathrm{b}} ;-4.2 \pm 0.3^{\mathrm{c}}$ \\
\hline $\log _{10}\left(\mathbf{P}_{\text {co2 }}, \mathbf{a t m}\right)$ & & $<-3.5$ & $-1.5^{\mathrm{d}}$ \\
\hline Total Organic C & $\mathrm{mM}$ & 32.0 & $1.01 \pm 0.25$ \\
\hline Total Inorganic $\mathbf{C}$ & $\mathrm{mM}$ & 0 & $12.7 \pm 1.4$ \\
\hline Total $\mathbf{C H}_{4}$ & $\mathrm{mM}$ & 0 & $10.4 \pm 1.9$ \\
\hline $\mathbf{C}$ mass recovery & & & $75 \%$ \\
\hline Ca & $\mathrm{mM}$ & 0 & $1.0 \pm 0.4$ \\
\hline $\mathbf{F e}$ & $\mathrm{mM}$ & 0 & $0.045 \pm 0.005$ \\
\hline $\mathbf{M n}$ & $\mathrm{mM}$ & 0 & $0.035 \pm 0.005$ \\
\hline
\end{tabular}

${ }^{a}$ In-situ pH measurements. ${ }^{b}$ From Pt electrodes. ${ }^{\mathrm{c}}$ From $\mathrm{pH}, \mathrm{CO}_{2}$ and $\mathrm{CH}_{4}$ data. ${ }^{\mathrm{d}}$ From $\mathrm{TIC}$ and $\mathrm{pH}$ data. 
Concentration of U, OC, and IC in effluents are shown in Figure 1. Initial U concentrations were very high, typically exceeding $10 \mu \mathrm{M}$, indicative of the initial oxidizing condition. Active microbial populations in the sediment were indicated by nearly complete OC conversion to bicarbonate and methane, and confirmed by microbial assays (discussed below). The decreased IC level (from 15 to $13 \mathrm{mM}$ ) after about day 215 resulted from the reduced flow rate (lower rate of OC supply). Direct analyses of the soils by $\mu$-XANES spectroscopy showed variable, but generally reduced conditions, with $87 \%( \pm 26 \%)$ of the U occurring as U(IV) on day 117 . Cumulative U removal in effluents at this time still left $98.8 \%$ of the initial $U$ in the soil. During this early stage of lactate infusion, $\mathrm{U}$ concentrations declined by 3 orders of magnitude, to less than $30 \mathrm{nM}$, by day 100 (10 pore volumes). For comparison, the U.S. EPA drinking water standard for U is $126 \mathrm{nM}^{18}$. Thus, in-situ reductive immobilization of $U$ appeared successful at this point.

However, upon further permeation with the lactate solution and sustained reducing conditions, $\mathrm{U}$ concentrations in effluents increased 30 -fold, back to over $1 \mu \mathrm{M}$ (days 120 to 200), thereafter remaining fairly constant. A similar trend was observed for total IC in effluents, with a steady-state concentration of $12.7 \mathrm{mM}$, primarily as $\mathrm{HCO}_{3}{ }^{-}$. Effluents also contained high levels of $\mathrm{CH}_{4}$ and $\mathrm{CO}_{2}$ (forming gas bubbles), and depleted levels of OC. The soil U(IV) content declined to $58 \%( \pm 22 \%)$ of the total U when measured on day 356. This latter set of $\mu$-XANES analyses were significantly different from the day 117 results at $\alpha=0.005$. Discharges of $U$ at elevated concentrations are expected to be sustainable for much longer times because cumulative leaching by day 475 still left $97.6 \%$ of the original $U$ in the soil. 


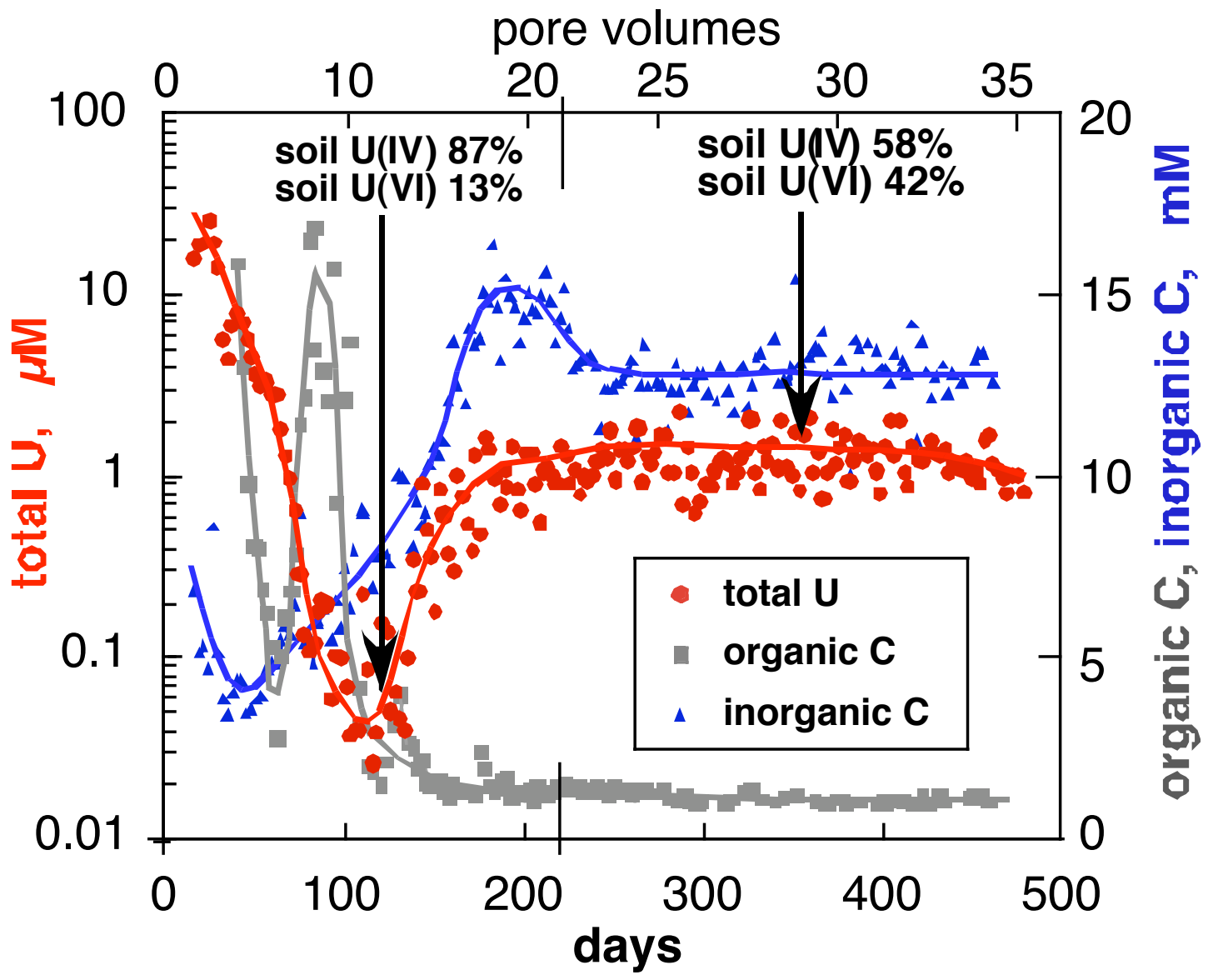

Figure 1. Concentrations of uranium, organic carbon, and inorganic carbon in effluents from soil columns. The data points are average values from 5 columns.

The microbial community composition in sediments was assessed ${ }^{17}$ from the $\mathrm{U}$ reduction and $\mathrm{U}$ oxidation stages (after 10 and 35 pore volumes of lactate infusion, respectively). Many bacterial species known to catalyze reduction of $U$ were identified including Geothrix sp., and members of the Geobacteraceae. The presence of these organisms was confirmed by PCR with specific primers. Although changes in community structure at different remediation stages were observed (results are not shown), the array and group-specific primer data indicated that a microbial community with the capacity for continued $U$ reduction remained through the end of the experiment 
(Table 2). The continuing presence of bacteria capable of metal reduction suggests that a loss of microbial functionality was not a factor in U(IV) re-oxidation.

Table 2. $16 \mathrm{~S}$ sequences of some known metal reducing bacteria detected by high density microarray analyses of extracts from column sediments during $U$ reduction and oxidation stages.

\begin{tabular}{|llll|}
\hline & & U reduction stage & U oxidation stage \\
OTU phylocode ${ }^{\mathrm{a}}$ & Representative organism & ${ }^{\mathrm{b}}$ Average difference & ${ }^{\mathrm{b}}$ Average difference \\
2.13.8.386 & Geothrix fermentans & $5312 \pm 134$ & $5369 \pm 508$ \\
2.28.4.7.4.10207 & Geobacter metallireducens & $5123 \pm 170$ & $5181 \pm 165$ \\
2.28.4.7.1.9784 & Pelobacter acetylenicus & $4466 \pm 104$ & $4603 \pm 153$ \\
2.28.4.11.9734 & Desulfobulbus propionicus & $5784 \pm 157$ & $5991 \pm 293$ \\
\hline
\end{tabular}

${ }^{a}$ Ribosomal Database Project (RDP) ( hierarchical phylogenetic code amended with specific OTU number. ${ }^{b}$ Average difference is the mean difference in intensity between all positive match probes and all corresponding mismatch probes within each probe set. Changes in average difference are indicative of relative changes in specific $16 \mathrm{~S}$ amplicon quantity and hence species abundance. No differences were significant $(p>0.05)$ for these OTUs between net reduction and net oxidation phases. Data are means of triplicates \pm standard error.

The cryogenic fluorescence spectrum of an effluent sample shows close resemblance to that of $\mathrm{Ca}_{2} \mathrm{UO}_{2}\left(\mathrm{CO}_{3}\right)_{3}$ (Fig. 2). The uranyl fluorescence decay (not shown) in the effluent sample has a lifetime of $1204 \mathrm{~s}$; consistent with that of the $\mathrm{Ca}_{2} \mathrm{UO}_{2}\left(\mathrm{CO}_{3}\right)_{3}$ complex, $1282 \mathrm{~s}$. Therefore, we conclude that uranyl in the effluent is primarily $\mathrm{Ca}_{2} \mathrm{UO}_{2}\left(\mathrm{CO}_{3}\right)_{3}$. 


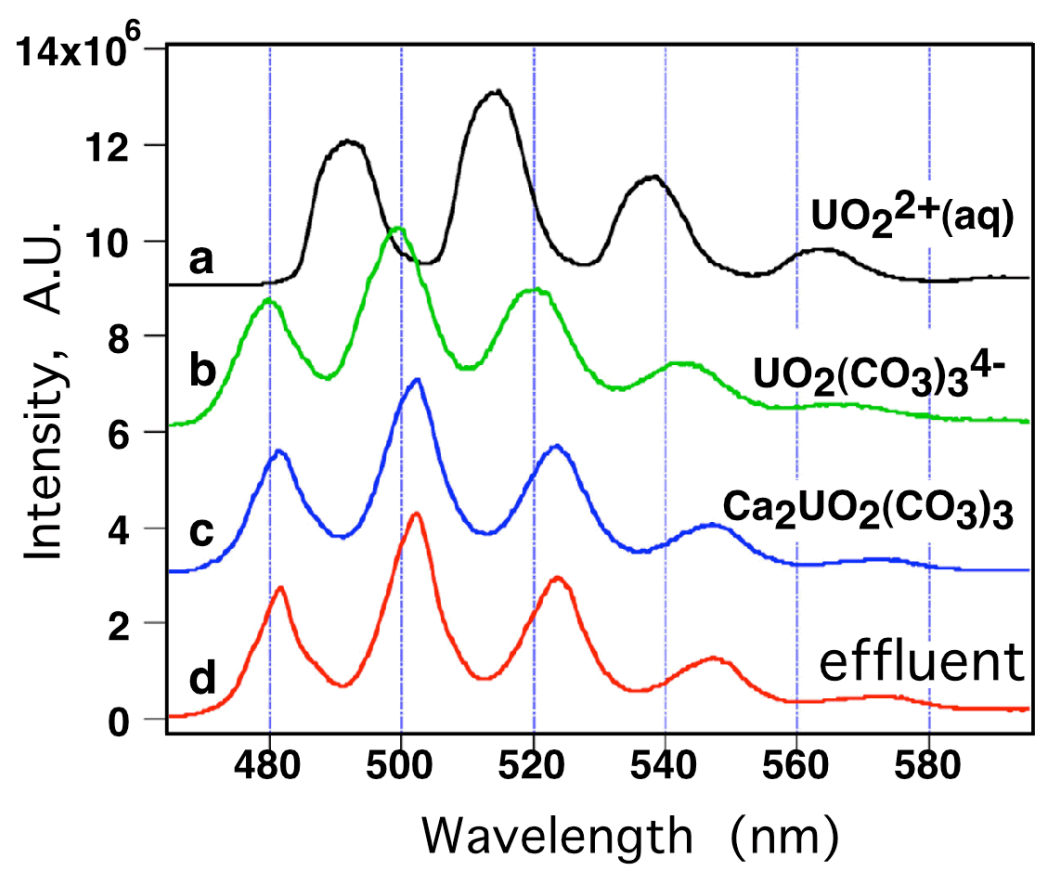

Figure 2. Fluorescence spectra of aqueous uranyl complexes at $6 \mathrm{~K}$. $\mathrm{l}_{\mathrm{ex}}=415$ $\mathrm{nm}$. The solution conditions are a) $\left[\mathrm{UO}_{2}{ }^{2+}\right]=5 \times 10^{-5} \mathrm{M}$ in nitric acid, $\mathrm{pH} 2.5$; b) $\left[\mathrm{UO}_{2}{ }^{2+}\right]=5 \times 10^{-6} \mathrm{M}$ in $0.034 \mathrm{M} \mathrm{Na}_{2} \mathrm{CO}_{3}$ solution, $P\left(\mathrm{CO}_{2}\right)=1 \mathrm{~atm}, \mathrm{pH}=10.6$; c) $\left[\mathrm{UO}_{2}{ }^{2+}\right]=1.17 \times 10^{-4} \mathrm{M},\left[\mathrm{NaHCO}_{3}\right]=7 \times 10^{-3} \mathrm{M},\left[\mathrm{Ca}^{2+}\right]=5 \times 10^{-3} \mathrm{M}, P\left(\mathrm{CO}_{2}\right)=$ $10^{-3.5}$ atm, $\mathrm{pH}=7.4$. d) column effluent, $\left[\mathrm{UO}_{2}{ }^{2+}\right]=2 \times 10^{-6} \mathrm{M}, P\left(\mathrm{CO}_{2}\right)=10^{-2.0}$ atm, $\mathrm{pH}=7.4 ; \quad$ For clarity, the spectra were normalized to the same maximum intensities and offset along the vertical axis.

Because reducing conditions are commonly associated with immobilization of $U$, the observed U solubilization under anoxic, nitrate-free, methanogenic conditions requires explanation. There are several key factors. One is the greatly increased (bi)carbonate concentration (blue line in Fig. 1) due to organic carbon oxidation. This increases $\mathrm{U}(\mathrm{VI})$ concentrations in solution through formation of $\mathrm{UO}_{2}{ }^{2+}-\mathrm{CO}_{3}{ }^{2-}$ solution complexes (Eqs 1-3 in Table 3), and through carbonate itself competing for sorption sites with $\mathrm{U}(\mathrm{VI})^{19}$. Another factor is the presence of calcite in sediments. The soil used in this experiment contained $3.0 \%$ of this common mineral. Calcium from calcite dissolution is 
effective in releasing $\mathrm{U}(\mathrm{VI})$ into solution through formation of $\mathrm{Ca}_{2} \mathrm{UO}_{2}\left(\mathrm{CO}_{3}\right)_{3}$ complexes at near-neutral $\mathrm{pH}^{5,16}$ (Eqs 4-5 in Table 3), which are much less susceptible to bioreduction ${ }^{20}$ and sorption ${ }^{21}$. Although the magnitude of $\mathrm{Ca}_{2} \mathrm{UO}_{2}\left(\mathrm{CO}_{3}\right)_{3}$ stability is currently unsettled ${ }^{22}$, it is acknowledged that neutral uranyl carbonate complexes with cations are important, and that the reported equilibrium constants ${ }^{5,16}$ are useful for guidance. Dissolved Ca concentrations in column effluents were about $1 \mathrm{mM}$, indicative of equilibrium with calcite. Also listed in Table 3 are the potentials for the dominant $U$ redox reactions under the experimental conditions $\left(\mathrm{Eh}^{\mathrm{b}}\right) . \mathrm{Eh}^{\mathrm{a}}$ are the potentials under the same conditions but lower carbonate concentration $\left(\mathrm{PCO}_{2}=10^{-3.5} \mathrm{~atm}\right)$. Comparison of $\mathrm{Eh}^{\mathrm{a}}$ and $\mathrm{Eh}^{\mathrm{b}}$ show that elevated carbonate concentrations do indeed, drive the potential of the $\mathrm{U}(\mathrm{IV}) / \mathrm{U}(\mathrm{VI})$ equilibrium more negative. For instance, the redox potentials $\left(E \mathrm{~h}^{\mathrm{b}}\right)$ for eqs 4 and 5 are around and below $-200 \mathrm{mV}$, well with in the range of the measured $\mathrm{Eh}$ values. Although carbonate and $\mathrm{Ca}^{2+}$ also promote displacement of sorbed U(VI) into solution, direct $\mu$-XANES measurements on the soils showed that a much larger inventory of U(IV) was oxidized to U(VI).

Table 3. Redox reactions and potentials

\begin{tabular}{|c|c|c|c|}
\hline Reactions & $E h^{\circ}(m V)$ & $\mathrm{Eh}^{\mathrm{a}}(\mathrm{mV})$ & $\mathrm{Eh}^{\mathrm{b}}(\mathrm{mV})$ \\
\hline 1. $\mathrm{UO}_{2} \mathrm{CO}_{3}+6 \mathrm{H}^{+}+2 \mathrm{e}^{-} \rightarrow \mathrm{UO}_{2}(\mathrm{~s})+\mathrm{HCO}_{3}^{-}$ & 278 & -62 & -121 \\
\hline 2. $\mathrm{UO}_{2}\left(\mathrm{CO}_{3}\right)_{2}^{2-}+2 \mathrm{H}^{+}+2 \mathrm{e}^{-} \rightarrow \mathrm{UO}_{2}(\mathrm{~s})+2 \mathrm{HCO}_{3}^{-}$ & 366 & -78 & -197 \\
\hline 3. $\mathrm{UO}_{2}\left(\mathrm{CO}_{3}\right)_{3}^{4-}+3 \mathrm{H}^{+}+2 \mathrm{e}^{-} \rightarrow \mathrm{UO}_{2}(\mathrm{~s})+3 \mathrm{HCO}_{3}^{-}$ & 531 & -17 & -195 \\
\hline 4. $\mathrm{Ca}_{2} \mathrm{UO}_{2}\left(\mathrm{CO}_{3}\right)_{3}+3 \mathrm{H}^{+}+2 \mathrm{e}^{-} \rightarrow \mathrm{UO}_{2}(\mathrm{~s})+3 \mathrm{HCO}_{3}^{-}+2 \mathrm{Ca}^{2+}$ & 278 & -181 & -240 \\
\hline 5. $\mathrm{CaUO}_{2}\left(\mathrm{CO}_{3}\right)_{3}{ }^{2-}+3 \mathrm{H}^{+}+2 \mathrm{e}^{-} \rightarrow \mathrm{UO}_{2}(\mathrm{~s})+3 \mathrm{HCO}_{3}^{-}+\mathrm{Ca}^{2+}$ & 427 & -76 & -195 \\
\hline 6. $\mathrm{Fe}(\mathrm{OH})_{3}+3 \mathrm{H}^{+}+\mathrm{e}^{-} \rightarrow \mathrm{Fe}^{2+}+3 \mathrm{H}_{2} \mathrm{O}$ & 976 & -78 & -78 \\
\hline 7. $\mathrm{MnO}_{2}$ (pyrolusite ) $+4 \mathrm{H}^{+}+2 \mathrm{e}^{-} \rightarrow \mathrm{Mn}^{2+}+2 \mathrm{H}_{2} \mathrm{O}$ & 1220 & 1180 & 1180 \\
\hline
\end{tabular}

${ }^{\circ}$ Standard redox potentials, data are from ref. $(5,6,22)$. ${ }^{a}$ Reduction potential under conditions: $\mathrm{PCO}_{2}=10^{-3.5} \mathrm{~atm}, \mathrm{pH} 7.4, \Sigma \mathrm{U}(\mathrm{VI})_{(\mathrm{aq})}=10^{-8} \mathrm{M}, \mathrm{Fe}^{2+}=4.5 \times 10^{-5} \mathrm{M}, \mathrm{Mn}^{2+}=3.5 \times 10^{-5} \mathrm{M}, \mathrm{Ca}^{2+}=10^{-1.5} \mathrm{M}$. ${ }^{\mathbf{b}}$ Reduction potential under experimental conditions: $\mathrm{PCO}_{2}=10^{-1.5} \mathrm{~atm}, \mathrm{pH} 7.4, \Sigma \mathrm{U}(\mathrm{VI})_{(\mathrm{aq})}=10^{-8}$ $\mathrm{M}, \mathrm{Fe}^{2+}=4.5 \times 10^{-5} \mathrm{M}, \mathrm{Mn}^{2+}=3.5 \times 10^{-5} \mathrm{M}, \mathrm{Ca}^{2+}=10^{-3.5} \mathrm{M}$. Note that $\left[\mathrm{Ca}^{2+}\right]$ is a dependence of $\mathrm{PCO}_{2}$. 
Figures $3 \mathrm{a}$ and $3 \mathrm{~b}$ are Eh-pH diagrams for $\mathrm{U}(\mathrm{VI})_{\mathrm{aq}}$ in equilibrium with amorphous uraninite, $\mathrm{UO}_{2}(\mathrm{am})$. The main equations considered are shown in Table 3. The shaded lines in Figure 3 are the boundaries of $\mathrm{U}(\mathrm{VI})_{\mathrm{aq}}\left(10^{-8} \mathrm{M}\right)$ in equilibrium with $\mathrm{UO}_{2}(\mathrm{am})$, under atmospheric $\mathrm{PCO}_{2}\left(10^{-3.5} \mathrm{~atm}\right)$ and the experimental $\mathrm{PCO}_{2}\left(10^{-1.5} \mathrm{~atm}\right)$. Comparisons of these two conditions show that increasing $\mathrm{PCO}_{2}$ shifts the $\mathrm{U}(\mathrm{VI})_{\mathrm{aq}} \mathrm{U}(\mathrm{IV})_{\mathrm{S}}$ equilibrium towards lower redox potentials. Furthermore, comparison of Figures $3 a$ (without $\mathrm{Ca}^{2+}$ ) and $3 \mathrm{~b}$ (equilibrium with calcite), illustrates the large shift in $\mathrm{U}(\mathrm{VI})_{\mathrm{aq}} / \mathrm{U}(\mathrm{IV})_{\mathrm{S}}$ redox equilibrium boundaries to lower potentials in systems containing calcite, especially for $\mathrm{pH}<8.0$. Also indicated in the diagrams are our measured ranges of soil $\mathrm{pH}$ and $\mathrm{Eh}$ (yellow boxes). These comparisons show that oxidation of $U(I V)$ is thermodynamically favourable in these reducing soils. Thermodynamic calculations on $\mathrm{UO}_{2}(\mathrm{am})$ solubility based on equations in Table 3 indicate that concentrations of $\mathrm{U}(\mathrm{VI})_{\mathrm{aq}}$ increase by orders of magnitude when $\mathrm{CO}_{2}$ partial pressure increases from $10^{-3.5}$ to $10^{-1.5}$ atm (other conditions constant). The U(VI) concentration also increases by several orders of magnitude with calcite present. The calculated predominance of $\mathrm{Ca}_{2} \mathrm{UO}_{2}\left(\mathrm{CO}_{3}\right)_{3}$ in solution was supported by fluorescence spectroscopy as noted previously. The calculated U(VI) concentrations for our experiment conditions are one order of magnitude lower than our measurements of $1 \mu \mathrm{M}$. This discrepancy may reflect a higher solubility for the very recently reduced $\mathrm{UO}_{2}(\mathrm{~s})$, often as nanoparticles ${ }^{23}$ and/or U(VI) surface precipitates ${ }^{24}$, relative to the amorphous $\mathrm{UO}_{2}(\mathrm{~s})$ in the database. 

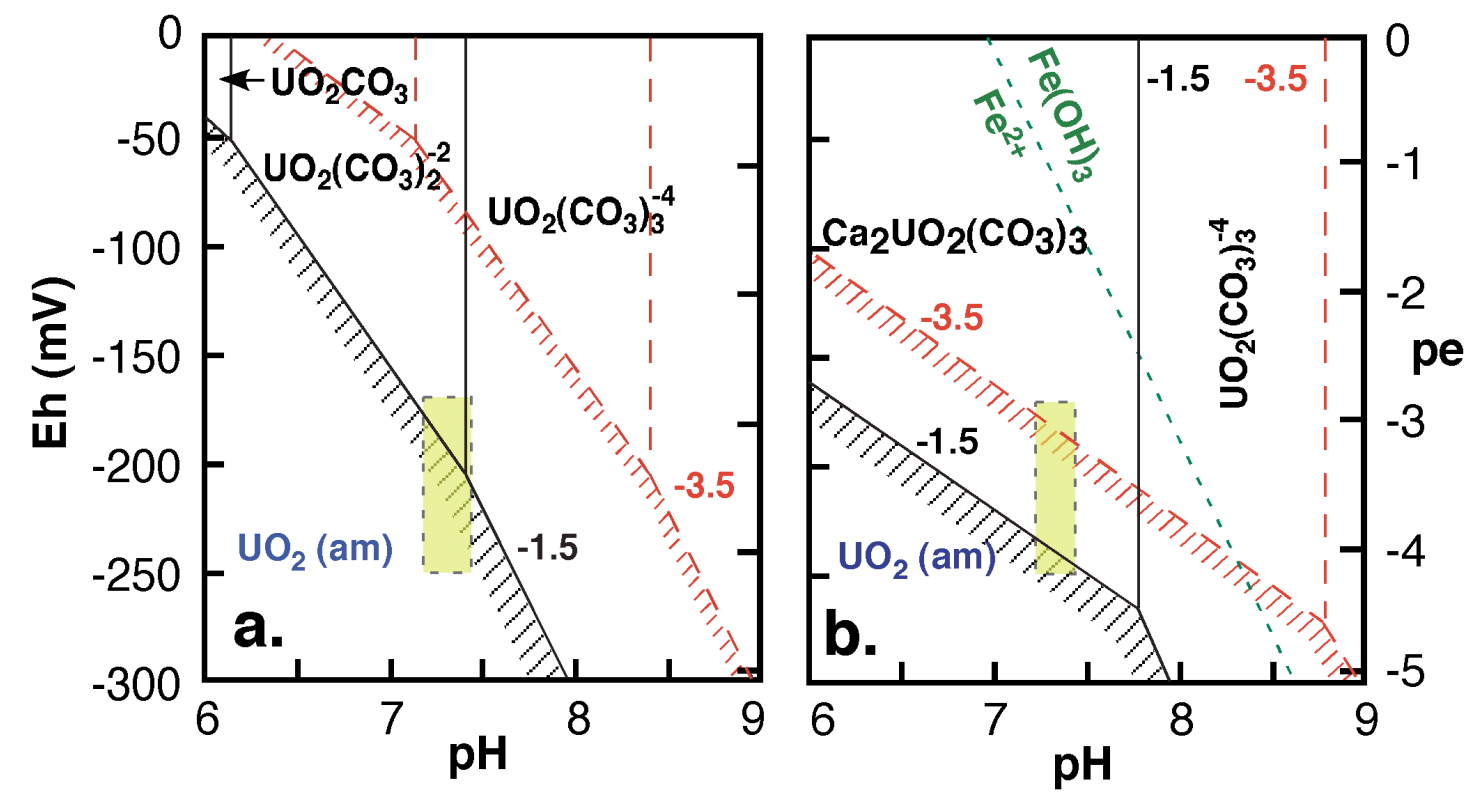

Figure 3. Eh-pH diagram of $\mathrm{U}(\mathrm{VI})_{\mathrm{aq}}$ equilibrium with $\mathrm{UO}_{2}(\mathrm{am})$ without $\mathrm{Ca}^{2+}(\mathbf{a})$ and with calcite (b), for $\sum \mathrm{U}(\mathrm{VI})_{\mathrm{aq}}=10^{-8} \mathrm{M}$, at $\log \mathrm{PCO}_{2}=-3.5$ (in red) and log $\mathrm{PCO}_{2}=-1.5$ (in black). For comparisons, the $\mathrm{Fe}(\mathrm{OH})_{3} / \mathrm{Fe}^{2+}\left(\mathrm{Fe}^{2+}=10^{-4} \mathrm{M}\right)$ redox transition is shown as a green dotted line in $2 \mathrm{~b}$. Our measured ranges of $\mathrm{pH}$ and Eh are shown as the yellow rectangle.

Although we demonstrated that $\mathrm{U}(\mathrm{IV})$ reoxidation became thermodynamically favorable in these reducing soils, the TEA(s) have not been identified. The likely TEA(s) in these soil columns are $\mathrm{Fe}(\mathrm{OH})_{3}$ and/or $\mathrm{MnO}_{2}$ for several reasons. First, the other potential TEAs, $\mathrm{O}_{2}, \mathrm{NO}_{3}{ }^{-} / \mathrm{N}_{2} \mathrm{O}$, and $\mathrm{SO}_{4}{ }^{2-}$ were undetectable in column pore solutions. Secondly, the redox potentials of $\mathrm{Fe}(\mathrm{OH})_{3} / \mathrm{Fe}^{2+}$ and $\mathrm{MnO}_{2} / \mathrm{Mn}^{2+}$ (as illustrated in Eqs. 67, and Fig. 3) are higher than that of the U(IV) oxidation transitions. Thirdly, poorly crystalline $\mathrm{Fe}(\mathrm{III})$ hydroxide and $\mathrm{MnO}_{2}$ are common minerals in soils. Our soil contained abundant $\mathrm{Fe}$ [ $4.4 \%$ total, and 3,650 $\mathrm{mg} \mathrm{kg}^{-1}$ in weak acid extractable form ${ }^{21,25}$, and Mn $\left[630 \mathrm{mg} \mathrm{kg}^{-1}\right]$. Fourthly, the measured steady-state $\mathrm{Fe}^{2+}$ and $\mathrm{Mn}^{2+}$ concentrations in the effluent solutions (45 and $35 \mu \mathrm{M}$, respectively) are supersaturated with respect to their 
carbonate solid phases (siderite and rhodochrosite, respectively ${ }^{26}$ ), and substantially greater than the effluent $\mathrm{U}(\mathrm{VI})$ concentrations $(1 \mu \mathrm{M})$. Finally, the ability of soil Fe(III) and $\mathrm{Mn}(\mathrm{IV})$ oxides to oxidize U(IV) in the presence of electron shuttles has been shown $^{27,28}$, and soluble Fe(III) has been found in the pore waters of reduced sedimentary material containing crystalline and/or amorphous Fe-oxides ${ }^{29}$.

This paper presents evidence that bioreduced $\mathrm{U}(\mathrm{IV})$ is reoxidized under reducing condition. Carbonate accumulation and calcite dissolution form highly stable $\mathrm{Ca}-\mathrm{UO}_{2}{ }^{2+}-$ $\mathrm{CO}_{3}$ complexes in near neutral and slightly alkaline conditions. Ubiquitous $\mathrm{Fe}(\mathrm{OH})_{3}$ and $\mathrm{MnO}_{2}$ in soil are the only likely TEAs responsible for U(IV) oxidation in this system. Although the effects of $\mathrm{pH}$, pe, $\mathrm{CO}_{2}$, and $\mathrm{Ca}^{2+}$ on $\mathrm{U}(\mathrm{VI})$ equilibrium are established $^{5,6,18,22}$, their implications on organic carbon based, reductive U stabilization have not previously been appreciated. This work also demonstrates the need for longterm experiments for evaluating remediation strategies that rely on transforming actinides and metals to low solubility products.

1. Riley, R. G., Zachara, J. M., \& F.J. Wobber. in Chemical Contaminants on DOE Lands and Selection of Contaminant Mixtures for Subsurface Science Research. U. S. Dept. Energy. Washington, DC (1992).

2. Uhrie, J. L., Drever, J. I., Colberg, P. J. S., \& Nesbitt, C. C. In situ immobilization of heavy metals associated with uranium leach mines by bacterial sulfate reduction. Hydrometallurgy 43, 231-239 (1996).

3. Abdelouas, A., Lu, Y., Lutze, W., \& Nuttall, H. E. Reduction of U(VI) to U(IV) by indigenous bacteria in contaminated ground water. J. Contam. Hydrol. 35, 217-233 (1998). 
4. Anderson, R. T. et al. Stimulating the in situ activity of Geobacter species to remove uranium from the groundwater of a uranium-contaminated aquifer. Appl. Environ. Microbio. 69, 5884-5891 (2003).

5. Bernhard, G. et al. Uranyl(VI) carbonate complex formation: Validation of the $\mathrm{Ca}_{2} \mathrm{UO} 2\left(\mathrm{CO}_{3}\right)_{3}$ (aq.) species. Radiochim. Acta 89, 511-518 (2001).

6. Langmuir, D. Aqueous Environmental Geochemistry (Prentice Hall, Upper Saddle River, NJ, 1997).

7. Lovley, D. R., Phillips, E. J. P., Gorby, Y. A., \& Landa, E. R. Microbial reduction of uranium. Nature 350, 413-416 (1991).

8. Lovley, D. R., Roden, E. E., Phillips, E. J. P., \& Woodward, J. C. Enzymatic iron and uranium reduction by sulfate-reducing bacteria. Marine Geology 113, 41-53 (1993). 9. Ganesh, R., Robinson, K. G., Reed, G. D., \& Sayler, G. S. Reduction of hexavalent uranium from organic complexes by sulfate- and iron-reducing bacteria. Appl. Environ. Microbio. 63, 4385-4391 (1997).

10. Fredrickson et al. Reduction of U(VI) in goethite $(\alpha-\mathrm{FeOOH})$ suspensions by a dissimilatory metal-reducing bacterium. Geochim. Cosmochim. Acta 64, 3085-3098 (2000).

11. de Pablo, J., et al. The oxidative dissolution mechanism of uranium dioxide. I. The effect of temperature in hydrogen carbonate medium. Geochim. Cosmochim. Acta 63, 3097-3103 (1999).

12. Finneran, K. T., Housewright, M. E., \& Lovley, D. R. Multiple influences of nitrate on uranium solubility during bioremediation of uranium-contaminated subsurface sediments. Environ. Microbiol. 4, 510-516 (2002). 
13. Senko, J. M., Istok, J. D., Suflita, J. M. \& Krumholz, L. R. In-situ evidence for Uranium immobilization and remobilization. Environ. Sci. Technol. 36, 1491-1496 (2002).

14. U.S. Department of Energy's Natural and Accelerated Bioremediation Research (NABIR) Program's Field Research Center http://public.ornl.gov/nabirfrc/ (2003).

15. Bertsch, P. M. \& Hunter, D. B. Applications of synchrotron-based X-ray microprobes. Chem. Rev. 101, 1809-1842 (2001).

16. Kalmykov, S. N. \& Choppin, G. R. Mixed $\mathrm{Ca}^{2+} / \mathrm{UO}_{2}{ }^{2+} / \mathrm{CO}_{3}{ }^{2-}$ complex formation at different ionic strengths. Radiochim. Acta 88, 603-606 (2000).

17. DeSantis, T. Z., Dubosarskiy, I., Murray, S. R., \& Andersen, G. L. Comprehensive aligned sequence construction for automated design of effective probes (CASCADE-P) using 16S rDNA. Bioinformatics 19, 1461-1468 (2003).

18. U.S. Environmental Protection Agency’s Maximum Contaminant Level for U, amendment to 40 CFR Part 141 (65 FR 76708, Dec. 7, 2000).

19. Duff, M. C., \& Amrhein, C. Uranium (VI) adsorption on goethite and soil in carbonate solutions. Soil Sci. Soc. Am. J. 60, 1393-1400 (1996).

20. Brooks, S. C. et al. Inhibition of bacterial U(VI) reduction by calcium. Environ. Sci. Technol. 37, 1850-1858 (2003).

21. Zheng, Z., Tokunaga, T. K., \& Wan, J. Influence of calcium carbonate on U(VI) sorption to soils. Environ. Sci. Technol. 37, 5603-5608 (2003).

22. Guillaumont, R. et al., Chemical Thermodynamics 5. Update on the Chemical Thermodynamics of Uranium, Neptunium, Plutonium, Americium, and Technetium, Nuclear Energy Agency (Elsevier, Amsterdam, 2003).

23. Suzuki, Y., Kelly, S. D., Kemner, K. M., \& Banfield, J. F. Nanometre-size products of uranium bioreduction. Nature 419, 134 (2002). 
24. Giammar, D. E., \& Hering, J. G. Time scales for sorption-desorption and surface Precipitation of Uranyl on Goethite. Environ. Sci. Technol. 35, 3332-3337 (2001).

25. Barnett, M. O., Jardine, P. M., \& Brooks, S. C. U(VI) Adsorption to heterogeneous subsurface media: Application of a surface complexation model. Environ. Sci. Technol. 36, 937-942 (2002).

26. Jensen, D. L. et al. The solubility of rhodochrosite $\left(\mathrm{MnCO}_{3}\right)$ and siderite $\left(\mathrm{FeCO}_{3}\right)$ in anaerobic aquatic environments. Appl. Geochem. 17, 503-511 (2002).

27. K. P. Nevin, D. R. Lovley. Potential for Nonenzymatic Reduction of Fe(III) via Electron Shuttling in Subsurface Sediments. Environ. Sci. Technol. 34, 2472-2478 (2000).

28. Fredrickson, J. K. et al. Influence of Mn oxides on the reduction of uranium (VI) by the metal-reducing bacterium Shewanella putrefaciens. Geochim. Cosmochim. Acta 66, 3245-3262 (2002).

29. Nevin, K. P., \& Lovley, D. R. Mechanisms for Fe(III) Oxide Reduction in Sedimentary Environments. Geomicrobiology J. 19, 141-159 (2002).

Acknowledgments We thank W. Lukens, S. Traina, and G. Sposito for very helpful suggestions. We also thank D. Watson, T. DeSantis, D. Joyner, J. Pena, M. Newville, G. Anderson, S. Baek and GSECARS staff for technical assistance. Funding was provided through the U. S. Department of Energy (DOE), NABIR Program, the Basic Energy Sciences, (BES) Geosciences Program, GeoSoilEnviroCARS (GSECARS), Advanced Photon Source (APS), Argonne National Laboratory. GSECARS is supported by the National Science Foundation - Earth Sciences, DOE- Geosciences and the State of Illinois. Use of the APS was supported by the DOE BES, Office of Energy Research. Fluorescence spectroscopic measurements were performed at the W.R. Wiley Environmental Molecular Sciences Laboratory, a national scientific user facility sponsored by the DOE's Office of Biological and Environmental Research. 
Competing interests statement The authors declare that they have no competing financial interests.

Correspondence and requests for materials should be addressed to J.W. (e-mail: jmwan@1bl.gov). 